IRA-International Journal of Education \& Multidisciplinary Studies ISSN 2455-2526; Vol.05, Issue 02 (2016)

Pg. no. 66-75

Institute of Research Advances

http://research-advances.org/index.php/IJEMS

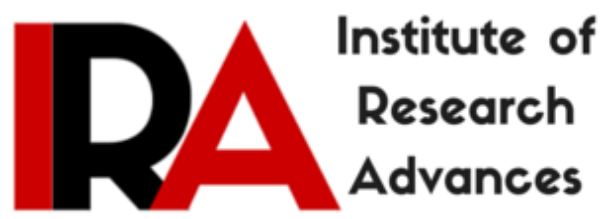

\title{
Learning Strategies Used by Public and Private School Mathematics Students of Nepal
}

Bishnu Khanal (Ph.D)

Tribhuvan University, Mahendra Ratna Campus,

Tahachal, Kathmandu, Nepal.

Type of Review: Peer Reviewed.

DOI: http://dx.doi.org/10.21013/jems.v5.n2.p2

\section{How to cite this paper:}

Khanal, B. (2016). Learning Strategies Used by Public and Private School Mathematics Students of Nepal. IRA International Journal of Education and Multidisciplinary Studies (ISSN 2455-2526), 5(2), 66-75. doi:http://dx.doi.org/10.21013/jems.v5.n2.p2

(C) Institute of Research Advances

\section{(cc) EY-NO}

This work is licensed under a Creative Commons Attribution-Non Commercial 4.0 International License subject to proper citation to the publication source of the work.

Disclaimer: The scholarly papers as reviewed and published by the Institute of Research Advances (IRA) are the views and opinions of their respective authors and are not the views or opinions of the IRA. The IRA disclaims of any harm or loss caused due to the published content to any party. 


\begin{abstract}
This paper attempts to find out the difference in preferred learning strategies in mathematics between public and private school students in Nepal. It is based on a study that was conducted among 1394 grade $I X$ students who were sampled following multistage sampling procedure throughout the country. Among them, 977 and 417 students were from public and private schools respectively. The author adopted mixed method-sequential explanatory design. . The tools for the data collection were questionnaire, observation and interview. The study found that there is significant difference in preferred learning strategies of public and private school students. Public school students preferred to use elaboration, help seeking and rehearsal strategies more often than private school students, whereas private school students were far ahead in using peer learning and effort management strategies than public school students.
\end{abstract}

Keywords: Mathematics students, preferred learning strategies, private school and public school

\title{
BACKGROUND OF THE STUDY
}

Nepalese school education can be categorized into two types from managerial perspective - viz. public and private. Public schools are run under the management of community or government body with government fund but private schools are run by the management and investment of an individual or group of individuals. Both types of schools have implemented the same curriculum but differences are notice between the two types of schools regarding the performance of students. This is revealed from the study of Mathema and Bista (2006) based on School Leaving Certificate (SLC) result 2004, which states:

It is clear that public schools, on average, lag far behind private schools in performance. Compared to an average pass rate of $85 \%$ for private schools, the figure for the public schools was only $38 \%$. Similarly, while an overwhelming majority of private schools showed pass rates in the $80-100 \%$ range, the same were less than $7 \%$ in the public schools. Also, the average SLC score of public schools was around $39 \%$ below that of private schools. (p. 77)

The study explored that majority of schools in Nepal during 2004 were public which comprised $73 \%$ in total, and about $79 \%$ of the students taking SLC examinations were from these schools; however, the performance of students was remarkably lower than that of the private schools.

In the level of performance, subject wise variance also played significant role in both public and private schools. Mathema and Bista (2006) further state that the average scores and pass rates for public schools are lower than those for private schools in all subjects, with particularly high pass rate differences in Mathematics, Science, and English. The study even disclosed that, in mathematics, the average score of public school students was 33.14 and pass rate was $56.88 \%$ whereas the average score of private school students was 57.69 and the pass rate was $89.31 \%$.

The achievement of private (institutional) school students was higher than that of public (community) schools, as shown by the huge study carried out by Ministry of Education, Education Review Office in 2011. The gap between the students of the two categories of schools was very high (Acharya, Metsämuuronen, \& Koirala, 2013). The report explains many variables that explain the variation; but it does not explain the learning strategies followed by the students of such schools. This study claimed that despite the physical facilities, socio-economic factors, teachers and parents, there were some differences in learning strategies to get the different result. Despite the effort to enhance the quality of education in both types of schools, the differences in the performance of students in the same curriculum has posed challenges.

There is a lack of academic research on the use of learning strategies in both public and private school students especially in mathematics education. The author was interested to investigate whether 
differences in the performance in mathematics between public and private school students are due to learner's preference in learning strategies. Learning strategies are individual's approach to a task. They determine how a student organizes and use his/her individual set of skills while learning the content to accomplish a particular task more effectively and efficiently either in or out of school (Schumaker \& Deshler, 1984). Learning strategies are specific actions employed by learners to make their learning easier, faster, more enjoyable, directed, effective and transferable to new situations.

The study of Protheroe and Clarke (2008) suggests that effective use of learning strategies can greatly improve student achievement. In order to improve the academic performance of all students in mathematics, teachers need to help students develop effective learning strategies that enable them to construct their own knowledge, discover relationships and find facts by adopting their own learning styles and strategies rather than simply memorizing mathematical formulas and procedures (Cangelosi, 1996).

Improvement of mathematics education is hardly possible without understanding the learners' strategies and difficulties. Hence, the present study aims to address this issue and thereby contribute to the advancement of quality mathematics education in the public and private schools of Nepal. The above mentioned practical experiences, theoretical backgrounds and the national context of mathematics education have inspired the author to explore the learning strategies used by Nepalese public and private school students during their compulsory mathematics lessons.

\section{RESEARCH QUESTIONS}

This study aims to answer the following two questions related to the learning strategies of Nepalese secondary school mathematics students:

1. Are there any differences between public and private school students in their preferred learning strategies in mathematics?

2. If so, what kinds of differences could be found?

\section{METHOD}

A mixed method-sequential explanatory design (Creswell, 2014) was employed for this study. Data were collected from 1394 mathematics students of grade IX representing 24 schools of three geographical regions of Nepal. Samples were selected through multi-stage sampling, and data were collected though surveys, interviews and observations. This study was based on the learning strategies classified by Pintrich, Smith and McKeachie (1989) to answer the research questions. Quantitative data was collected by adapting Motivated Strategies for Learning Questionnaire (MSLQ) developed by Pintrich, Smith and Mckeachie (1989). The questionnaire includes motivation scales and learning strategies scales, which can be used together or separately (Chang, 2010). In the present study, only the learning strategies section was utilized.

The learning strategies consisted of cognitive strategies which include rehearsal (4 items), elaboration (6 items), organization (4 items), critical thinking ( 5 items), metacognition (10 items), and resource management strategies which include time and study management (5 items), effort management ( 3 items), peer learning ( 3 items), and help seeking ( 3 items). The learning strategies section of the MSLQ contains two categories with 43 items in 7-point Likert-type scale, ranging from 1 (not at all true of me) to 7 (absolutely true of me). Each item represents a statement concerning the use of learning strategy. The learning strategies section of the MSLQ was translated into Nepalese version by the researcher with the consultation of English and Nepali language experts. The pilot test of the translated instrument was carried out in the small group of students. Overall, Cronbach's alpha reliability for internal consistency of all the 43 items was 0.85 . Hence, from reliability point of view, the items were reliable enough to use in research. Survey was used to identify the learning strategies of mathematics students. In the study, any 
scale score is calculated by taking the mean of the responses to all items in the particular scale. The data were analyzed by applying $\chi^{2}$ - test through SPSS and interpreted using diagrams and tables.

For the qualitative study, the author employed observation and interview method. Observation guidelines were prepared prior to the observation. The author observed 30 lessons of two schools. Similarly, interview guidelines were prepared based on the learning strategies as classified by Pintrich, Smith and McKeachie (1989). 24 key respondents with equal number of boys and girls were selected from two of the schools after observation for interview. Interviews were taken individually and recorded in a video camera as well as in an audio-recorder. The re-interviews were also taken and recorded to obtain the missing information and triangulate them with the information obtained from initial interviews and class observation.

Cohen, Manion and Morrison (2007) state: "Qualitative data analysis involves organizing, accounting for and explaining the data; in short, making sense of data in terms of the participants' definitions of the situation, noting patterns, themes, categories and regularities" (p. 461). The collected qualitative information from observation and interview were transcribed, encoded and categorized thematically. Thematic categories were based on learning strategies-rehearsal, elaboration, organization, critical thinking, metacognition, effort management, peer learning, and help seeking in terms of school types. The information was critically analyzed substantiating with theory and the results of the previous studies and interpreted from the texts, narrations and reflective points. Then the integration was made in sequential order; first quantitative analysis and interpretation followed by qualitative analysis and interpretation. During integration, coherent issues were agreed and conflicting issues were discussed and debated. Reinterviews were also taken and recorded for cross-checking and triangulation with the information obtained from initial interviews and class observation to maintain the reliability, validity and trustworthiness of the data as stated by Creswell (2014).

The secondary data and information about mathematics achievement of the students were collected from two case schools. The data were accumulated from the marks ledger of District Level Exam of the previous grade (grade VIII) as provided by the school.

\section{RESULTS AND DISCUSSION}

As the analysis of quantitative data reveals, most of the public school students (23\%) used peer learning and elaboration strategies whereas most of the private school students $(30.5 \%)$ used peer learning alone. Altogether $14.5 \%$ of public school students used help seeking, $11.5 \%$ used rehearsal, $9.6 \%$ used effort management, $8.6 \%$ used organization, $4.8 \%$ used time and study management, $2.8 \%$ used metacognition and $1.8 \%$ used critical thinking strategies. Similarly, $15.6 \%, 14.9 \%, 11.8 \%, 9.6 \%, 8.6 \%, 5 \%, 2.2 \%$ and $1.9 \%$ of private school students used elaboration, effort management, help seeking, rehearsal, organization, time and study management, metacognition and critical thinking strategies respectively. The ordered percentage of public and private school students has been plotted in the bar graph as demonstrated in figure 1 below: 


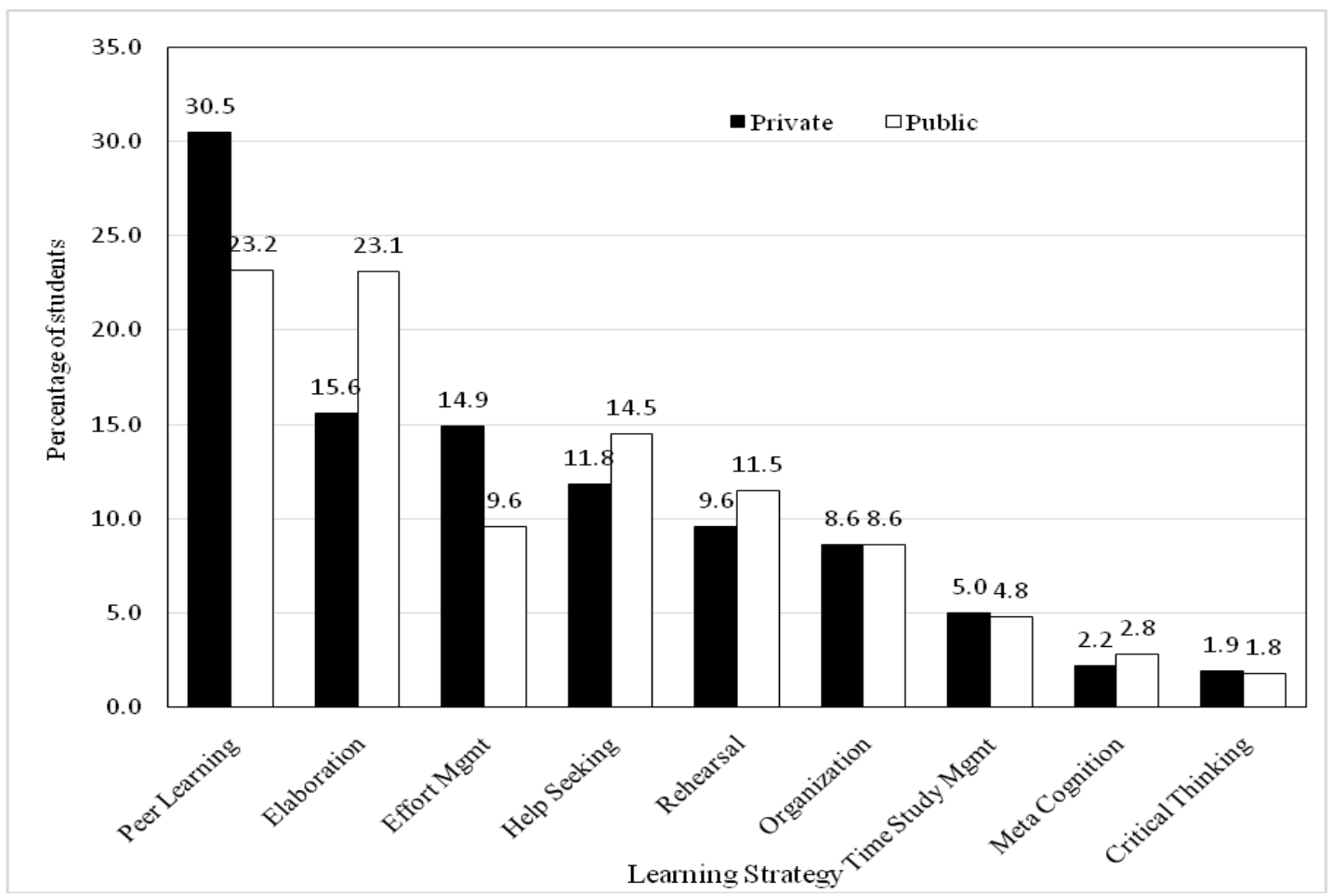

Figure 1: Plot of learning strategies against percentage of students in private and public schools

Figure 1 reveals that peer learning was the most frequently used learning strategy among the students of public as well as private schools. Peer learning and elaboration were used more or less equally by public school students. Public school students preferred to use elaboration, help seeking and rehearsal strategies more often than private school students, whereas private school students were far ahead of public schools in peer learning and effort management. They were also found ahead of public school students in using the strategies of time and study management and critical thinking.

Table 1 displays the frequency of students from public and private schools adopting the different learning strategies in mathematics learning.

Table 1: Observed and expected counts of learning strategies used by public and private school students

\begin{tabular}{llccc}
\hline Selected Strategy & & School Type & & Total \\
\cline { 3 - 5 } & & Public & Private & \\
\hline Rehearsal & Observed Count $^{*}$ & 112 & 40 & 152 \\
Elaboration & Expected Count $^{*}$ & 107 & 46 & 152 \\
& Observed Count $_{\text {Organization }}$ & 226 & 65 & 291 \\
& Expected Count & 204 & 87 & 291 \\
Critical thinking & Observed Count & 84 & 36 & 120 \\
\multirow{3}{*}{ Metacognition } & Expected Count & 84 & 36 & 120 \\
& Observed Count & 18 & 8 & 26 \\
Time_Study_Mgmt & Expected Count & 18 & 8 & 26 \\
& Observed Count & 27 & 9 & 36 \\
& Expected Count & 25 & 11 & 36 \\
& Observed Count & 47 & 21 & 68 \\
\hline
\end{tabular}




\begin{tabular}{llccc}
\hline \multirow{3}{*}{ Effort_Mgmt } & Expected Count & 48 & 20 & 68 \\
& Observed Count & 94 & 62 & 156 \\
Peer_Learning & Expected Count & 109 & 47 & 156 \\
& Observed Count & 227 & 127 & 354 \\
Help_Seeking & Expected Count & 248 & 106 & 354 \\
& Observed Count & 142 & 49 & 191 \\
& Expected Count & 134 & 57 & 191 \\
\hline Total & & 977 & 417 & 1394 \\
\hline
\end{tabular}

The null hypothesis assumed by the research question was: Both public school students and private school students used all nine strategies in equal proportion. The chi-square test for goodness of fit was carried out to test the null hypothesis. The test showed the result given in Table 2.

Table 2: Chi-squared Test

\begin{tabular}{lccc}
\hline & Value & df & Asymp. Sig. (2-sided) \\
\hline Pearson Chi-Square & $24.206^{\mathrm{a}}$ & 8 & 0.002 \\
$\mathrm{~N}$ of Valid Cases & 1394 & & \\
\hline
\end{tabular}

${ }^{\mathrm{a}} 0$ cells $(0.0 \%)$ have expected count less than 5 . The minimum expected count is 7.78 .

The result was statistically significant (at $\mathrm{p}<0.05$ ) and concluded that the learning strategy between the students of public schools and private schools differed in many ways; however, mostly used strategies were common in both types of schools.

Students' perception towards teaching and learning mathematics, their attitude towards mathematics, classroom management and student participation were important factors for the development of students' learning strategies. Students were interviewed regarding their needs, feeling, difficulty in learning and the strategies they used in learning mathematics. Public school students in the interview said that mathematics was difficult subject. This version was from the students who participated less in classroom activities, those who were back-benchers in the classroom, and those who tried to keep themselves away from the eyes of the teachers in the class. There were low achievers in private schools also. However, they were encouraged by their teachers for participation in learning processes. Thus, private school teachers tried to minimize the students' anxieties in learning mathematics. They created positive attitude among students. So, they were found active in learning compared to their counterparts in public schools. The researcher found that private school teachers encouraged active participation of the students. Group discussions were conducted, and sufficient teaching materials were used by the teachers; however, these factors were totally lacking in the public school observed by the researcher. These behaviours made private school students more attentive, while public school students tried to escape from mathematics class. In the interview, one of the public school students said, "I feel as if I should not study maths." Similarly, private school teachers were in easy reach to the students, but students could not easily tell problems to their teachers in public school. The intimacy between students and teachers found in private school was lacking in public school. If students wanted to ask question, the public school teacher called them in the office. The students feared as well as felt nervous, so they gave up the courage of asking question. One of the respondents asserted, "I want teachers teach the weak students separately, but I haven't got that opportunity. Teachers told me to go to the office and ask, but I feel nervous there, I become more confused." Likewise, most of the guardians of the students of public school were uneducated, but private school guardians were mostly educated. So, public school students rarely got chance to ask their family members for help; however, private school students had a higher chance to get help. "There is no one to teach me at home", admitted a public school student in the interview. But, "my sister teaches me at home" was the remark of a private school student. 
As mentioned above, the environment at school and at home played role in the choice of learning strategies used by learners in mathematics. Private school students were more likely to use peer learning and effort management strategies. As the co-operative environment was created in the private school, they were naturally likely to use peer learning as the most preferred strategy. Although the students of public school also used more peer learning than other strategies, private schools excelled the public schools in comparison. Similarly, public school students were more likely to use elaboration strategies than private school students. The public school students had the babit of taking notes; and they used it as the ultimate means during their practice. They lacked other materials. One of the public school students said, "I keep notes while the teacher teaches, and solve the other problems looking upon the same notes and practice solving other problems. I even remember the skills I had studied in the previous classes." Public school students also used effort management to a greater extent than private school students. As they lack other means, referring to the notes and practicing accordingly is their strategy of learning to pass exam in mathematics. Though the guardians of public school students were uneducated and teachers were less cooperative, the students were more likely to seek help from others than private school students. "Teacher indicates the important questions, which I tick and write very important", said a public school student. Another student from the same school said, "I feel the teacher should care weak students more." They had the expectation for help. In some cases, they got help. In some cases, they did not. Private school students were lagging behind in using elaboration, help seeking and rehearsal compared to the public school students. But public school students were back in peer learning, effort management and critical thinking. The attitude and environment, perception, average score and distinct learning strategies are summarized in table 3.

Table 3: Attitude and environment, perception, average score and learning strategies of public and

\begin{tabular}{|c|c|c|c|c|}
\hline $\begin{array}{l}\text { School } \\
\text { Type }\end{array}$ & Attitude and Environment & Perception & $\begin{array}{l}\text { Average } \\
\text { Score }\end{array}$ & $\begin{array}{l}\text { Learning } \\
\text { Strategies }\end{array}$ \\
\hline Public & $\begin{array}{l}\text { Poor classroom management, lack } \\
\text { of teaching-learning materials, } \\
\text { inclusive in students' admission, } \\
\text { uneducated guardians, poor family } \\
\text { background, no intimacy with } \\
\text { teachers, non-cooperative } \\
\text { environment, lack of individual care }\end{array}$ & $\begin{array}{l}\text { Mathematics is } \\
\text { difficult subject. } \\
\text { "I wish I } \\
\text { shouldn't study } \\
\text { mathematics." }\end{array}$ & 44.05 & $\begin{array}{l}\text { Elaboration, } \\
\text { help seeking, } \\
\text { rehearsal }\end{array}$ \\
\hline Private & $\begin{array}{l}\text { Effective classroom management, } \\
\text { sufficient teaching/learning } \\
\text { materials, selective in students' } \\
\text { environment, educated guardians, } \\
\text { financially sound, teachers' } \\
\text { encouragement, cooperative } \\
\text { environment, individual care }\end{array}$ & $\begin{array}{l}\text { Mathematics is } \\
\text { an important } \\
\text { subject. } \\
\text { "We need } \\
\text { mathematics for } \\
\text { our further } \\
\text { study." }\end{array}$ & 65.48 & $\begin{array}{l}\text { Peer learning, } \\
\text { effort } \\
\text { management, } \\
\text { critical } \\
\text { thinking }\end{array}$ \\
\hline
\end{tabular}

Although both public and private school students used all nine strategies to some extent, table 3 clearly displays that public school students excelled in some strategy and private school students excelled in others. However, the various contextual factors made significant differences in the choice of learning strategies between public and private school students.

The learning strategies adopted by public and private school students differed significantly - resulting into a great difference in the achievement level. From the study of the information presented above, we can infer that the use of learning strategies was determined by how students perceived mathematics, their attitude towards mathematics subject, their participation in learning and the classroom environment. In private schools, the teachers co-operated students and encouraged them for their own participation in 
learning mathematics; however, public school teachers were seen indifferent regarding student participation and the use of learning strategies. In the private school classrooms, activities among peer groups were encouraged, so students were able to learn more from their peers. This finding is in conformity with the statement "Private school students are more heavily exposed to in-class work and exercises. Private school students also have an advantage over public school students in terms of the learning environment provided by their peer groups." (World Bank, 1995, p. 77).

Effective teaching and learning cannot take place in a poorly managed classroom. If students are disorderly and disrespectful and no apparent rules and procedures guide their behavior, chaos becomes the norm. Well-managed classrooms provide an environment in which teaching and learning can flourish (Ahmad, n.d.). Many research studies have concluded that a conducive classroom environment promotes students' academic achievement (Ahmad, n.d.). Classroom management was poor in public schools. In private schools, by contrast, classroom management was done effectively.

Classroom management strategies are a crucial part of teachers' success in creating a safe and effective learning environment for students. The purpose of education is to provide a safe and friendly environment in order for learning to take place. Therefore, teachers should know how to use and apply the strategies that will help students to learn (Ahmad, n.d.). Classroom management refers to all the things that a teacher does to organize students, the space available, time and materials used to foster students' involvement and co-operation in all classroom activities. It is an ability of the teacher to cooperatively manage classroom activities by motivating students to develop effective learning strategies. As the public schools lack effective classroom management and private schools incorporate even the behavioral aspects of students, they are more likely to develop and use more learning strategies than public school students.

In Nepal, classroom sitting arrangements are made in both types of schools but behavioral problems are not addressed in public schools. But this aspect is addressed in private schools. The researcher found that private school teachers encouraged students for active participation, and group discussions were conducted, but such activities were missing in public schools. Likewise, private school teachers were in intimate relation with students while public school teachers created distance between themselves and their students. The activities of private school teachers, thus, facilitated their students to use a lot of strategies as per their need, but public school students had to rely on some limited strategies. Public school students were more likely to use elaboration, help seeking and rehearsal, but private schools students were more likely to use peer learning, effort management and critical thinking as effective learning strategies. However, students in both types of schools were seen using all nine strategies in varied frequencies. The private school students used strategies more effectively as they had technology, resource and well managed classroom facilities; but public school students lacked these facilities. As they were from poor family background, they sought more help from their teachers and elders and practised themselves more to perform better in the exams. They had to elaborate the materials themselves and used their prior knowledge to learn mathematics. In effort management, public school students were below private school students because they were mostly teacher dependent, the teachers did not encourage them to use their own effort in learning. Regarding time and study management also, private school students were found ahead of public school students. It was because of the family background and economic situation of the students. As they had uneducated family, they had to manage time for household work and for looking after their younger siblings. All above mentioned factors contributed a lot for the use of learning strategies, and the significant difference could be seen between public and private school students.

\section{CONCLUSIONS}

There is a significant difference between public and private school students regarding their tendency of using learning strategies. Public school students prefer to use elaboration, help seeking and rehearsal more often than private school students, whereas private school students are far ahead of their public school 
counterparts in using peer learning and effort management than public school students. Private school students are encouraged and cooperated by their teachers to participate in learning process; however, public schools are indifferent regarding students' participation. Private school students are encouraged to participate in peer group activities, and are exposed to in-class works and exercises. Similarly, classroom management is also found different. Classroom management is done in both public and private schools, but behavioural aspect is addressed more in private schools - which is often ignored in public schools. Use of teaching learning materials also creates differences. Private school teachers use the teaching materials additional to textbooks, and try to facilitate students' learning; but this aspect is lacking in public schools. Likewise, the anxieties of students in public schools about mathematics also affect the use of learning strategies.

The study implies that private school teachers are cooperative and encourage students to perform activities in peer groups by exposing them to in-class works and exercises - compared to the public school teachers who are indifferent towards students' participation. Similarly, private school teachers use more teaching materials than public school teachers; therefore, it would be better to suggest that public school teachers become more cooperative and facilitative in students' learning. Teachers in both types of schools are expected to use teaching materials. More particularly, public school teachers are expected to use more teaching materials while teaching mathematics to the secondary students. In the same vein, teachers are expected to carefully observe their students' problems related to personal behavior and decide how to manage classroom addressing the problems that emerge from varied ability groups, sex, social, cultural, ethnic and economic background. It is also worthwhile to note that more interpersonal relationships help children to reduce anxiety and tension, increase self-esteem among the students, reduce alienation and loneliness, and provide freedom to talk aloud, and explore thoughts and ideas with one another by maintaining discipline in the classroom.

\section{References}

Acharya, S. P., Metsämuuronen, J., \& Koirala, S. (2013). National assessment of student achievement 2011. In J. M. (Eds), Where Are We Now? (p. 468). Kathmandu: Education Review Office.

Ahmad, M. (n.d.).Application of classroom management strategies in public and private sector at school level in Pakistan.Journal of Managerial Sciences 4(1), (55-64).

Cangelosi, J. S. (1996). Teaching mathematics in secondary and middle school: An interactive approach (2nd ed.). NJ: Prentice Hall, Inc.

Chang, Y. -C. (2010). Students'perceptions of teaching styles and use of learning strategies.Masteral Thesis, University of Tennessee.

Cohen, L. Manion, L. \& Morrison, K. (2007). Research methods in education. London and NewYork: Routledge.

Creswell, J. W. (2014). Research design: Qualitative, quantitative, and mixed methods approaches. New Delhi: SAGE Publications India Pvt. Ltd.

Mathema, K. B. \& Bista, M. B (2006).Study on student performance in SLC: Main report. Kathmandu: Ministry of Education and Sports, Education Sector Advisory Team.

Pintrich, P. R., Smith, D. A. F., \& Mckeachie, W. J. (1989). A manual for the use of the motivated strategies for learning questionnaire (MSLQ). Mich: National center for Research to improve Postsecondary Teaching and Learning (NCRIPTAL), School of Education, The University of Michigan.

Protheroe, N. \& Clarke, S. (2008). Learning strategies as a key to student success. Principal, 88(2), 3337. 
Schumaker, J. B., \& Deshler, D. D. (1984). Setting demand variables: A major factor in program planning for LD adolescents. Topics in language disorders, 4, 22-44.

World Bank (1995).Public and private secondary education in developing countries: A comparative study. Washington. D.C.: The World Bank. 